Volume 3, Number 2, 2017

\title{
Improvement of Pulse-Width Modulation Algorithm for Thermal Plant Control
}

\author{
Roman Fedoryshyn", Sviatoslav Klos, Volodymyr Savytskyi, Sergiy Kril \\ Lviv Polytechnic National University, 12 Stepan Bandera St., Lviv, 79013, Ukraine
}

Received: November 08, 2017. Revised: November 29, 2017. Accepted: December 06, 2017.

(C) 2017 The Authors. Published by Lviv Polytechnic National University.

\begin{abstract}
The results of the pulse-width modulation algorithms analysis are presented in the paper. The following two algorithms are analyzed: pulse-width modulator (PWM) based on the sawtooth waveform generator and PWM based on an integrator and a switch element. Mathematical formulae for designing the tuning parameters of PWM algorithms are presented. An improved PWM algorithm is suggested for a programmable logic controller (PLC) operating with integer variables without a filter of the input signal. The improved algorithm provides elimination of the influence of the input signal's noise on the PLC output signal. PLC output relay contact bouncing is eliminated by means of the improved algorithm. The reliability of PLC is improved and the operation time of PLC output relay contact is prolonged thanks to the improved PWM algorithm. The example of PWM application in an automatic controller for controlling a thermal plant is presented. The advantages of the improved PWM algorithm application are demonstrated. The technique for PWM pulses period defining with taking into account the dynamical properties of the controlled plant is presented.
\end{abstract}

Keywords: pulse-width modulator; algorithm; duty cycle; integrator; comparator; switch.

\section{Introduction}

The pulse-width modulation is often applied during automation of technological processes in particular for controlling the rotation speed of an electric motor and for controlling a thermal plant. One more example of a pulsewidth modulator (PWM) application is a step controller for controlling an electric actuator with a constant speed of movement. The diagram of such a controller consists of a continuous PID controller, a differentiation element and a pulse-width modulator [1]. Application of PWM in an automatic controller provides efficient control of a thermal plant with high quality of the transient processes.

The goal of this work is to analyze the existing pulse-width modulation algorithms and to present the improved PWM algorithm. The following two existing algorithms are analyzed: PWM based on the sawtooth waveform generator and PWM based on an integrator and a switch element. This paper also aims at analyzing the quality of the transient processes in the system where PWM is applied for controlling a thermal plant.

\section{PWM algorithm based on the sawtooth waveform generator}

The pulse-width modulator is a device or a diagram in which the width of pulses at the output is defined by the value of the analog signal at the input [2]. The main parameter of the output pulse signal is the duty cycle $(\gamma)$. It is the ratio of pulse duration to the period of pulses:

$$
\gamma=\frac{W}{\tau} 100 \%
$$

where $W$ is the pulse duration (width); $\tau$ is the period of pulses.

\footnotetext{
* Corresponding author. Email address: romanfedoryshyn@yahoo.com
}

This paper should be cited as: R. Fedoryshyn, S. Klos, V. Savytskyi, S. Kril. Improvement of pulse-width modulation algorithm for thermal plant control. Energy Eng. Control Syst., 2017, Vol. 3, No. 2 , pp. 63 - 72. https://doi.org/10.23939/jeecs2017.02.063 
One of the most widespread methods for pulse-width modulation is application of the sawtooth waveform generator and a comparator. This method is also called the intersective method. The sawtooth waveform can be generated by means of an integrator which provides linear variation of the output signal. When the signal reaches its maximum value the integrator is zeroed. The analog input signal of PWM diagram is compared to the current value of the integrator output signal by means of the comparator. The condition of the comparator operation can be described as follows

$$
\left\{\begin{array}{l}
Z=" 1 " \quad \text { at } \quad Y<A \\
Z=" 0 " \quad \text { at } \quad Y \geq A
\end{array}\right.
$$

where $Z$ is the PWM output signal; $A$ is the analog input signal of PWM; $Y$ is the integrator output signal.

The dynamic characteristics of operation of PWM algorithm based on the sawtooth waveform generator and a comparator is presented in Fig.1. A simplified flowchart of this algorithm is presented in Fig.2. The algorithm presented in Fig. 2 is accomplished within one scan cycle of the controller.

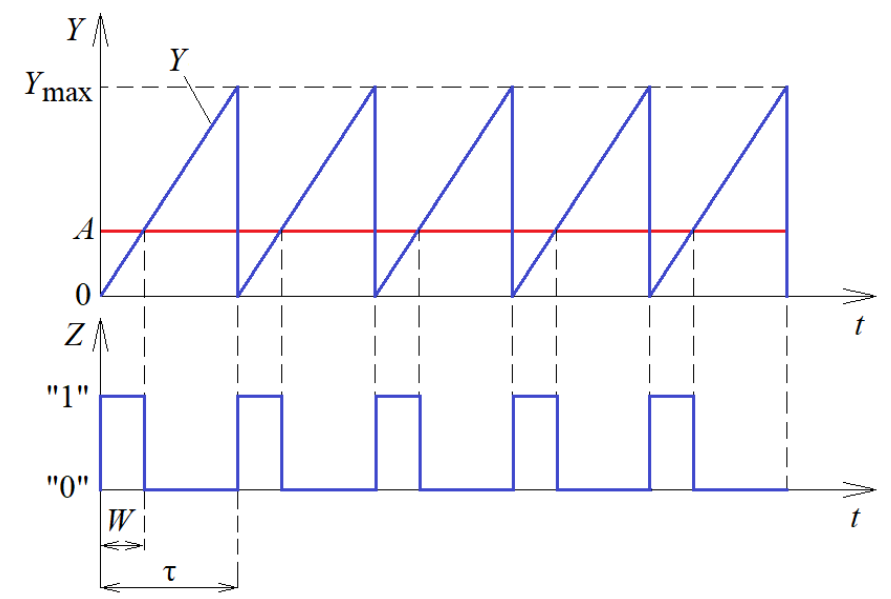

Fig.1. Dynamic characteristics of operation of PWM algorithm based on the sawtooth waveform generator.

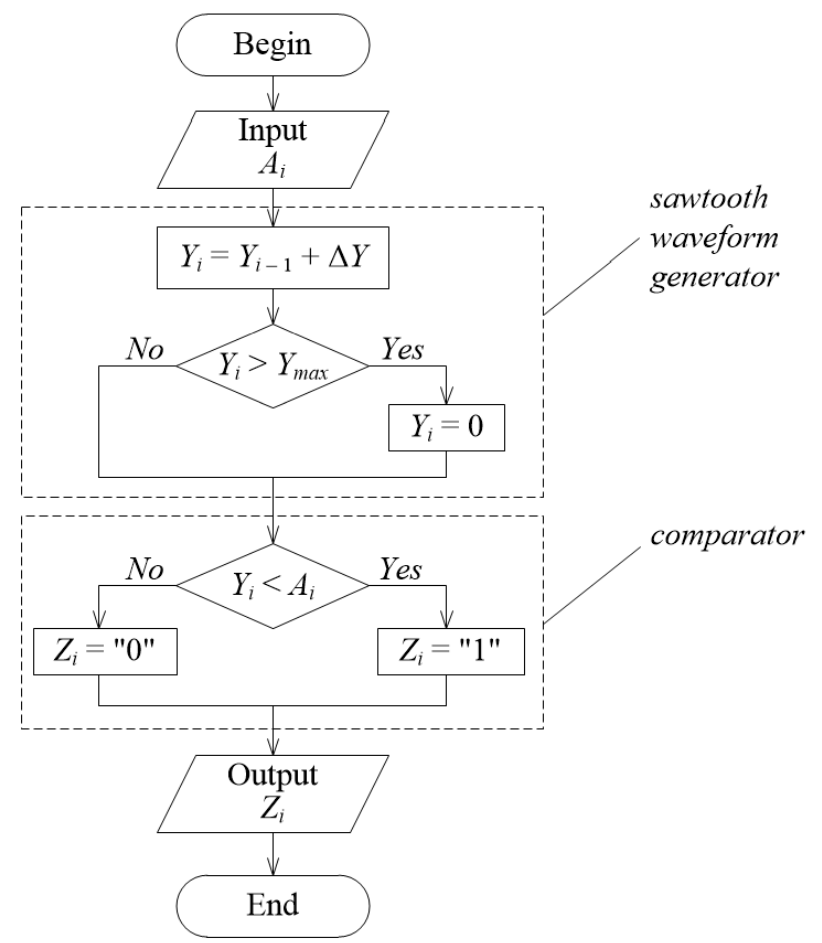

Fig.2. Simplified flowchart of PWM algorithm based on the sawtooth waveform generator and a comparator. 
The algorithm based on the sawtooth waveform generator and a comparator is applied in most up-to-date programmable logic controllers for pulse-width modulation.

\section{PWM algorithm based on an integrator and a switch element}

Another option of pulse-width modulation is to apply the diagram based on an integrator and a switch element with a negative feedback (see Fig.3).

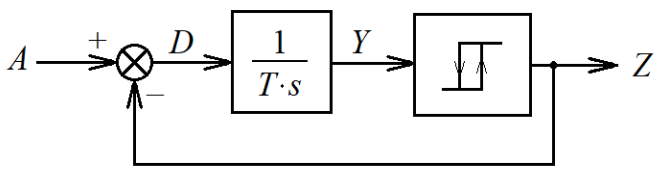

Fig.3. PWM diagram based on an integrator and a switch element.

This diagram can be tuned in the following way. The condition of the switch element operation is as follows

$$
\left\{\begin{array}{l}
Z=0 \quad \text { at } \quad Y<0 \\
Z=100 \quad \text { at } \quad Y \geq \Delta_{H L},
\end{array}\right.
$$

where $Y$ is the integrator output signal; $\Delta_{H L}$ is the hysteresis loop width of the switch element.

For the given values of the period of pulses $(\tau)$, the integrator time constant $(T)$ and the analog input signal $(A)$ the hysteresis loop width of the switch element can be calculated as

$$
\Delta_{H L}=\frac{\tau}{T} \cdot \frac{A}{100}(100-A)
$$

There is a corresponding algorithm for the diagram presented in Fig.3. This algorithm is presented in Fig.4 and it is accomplished within one scan cycle of $\Delta t$ duration in the controller. The diagram based on an integrator and a switch element is implemented in PROTAR-110 [3] controller for pulse-width modulation.

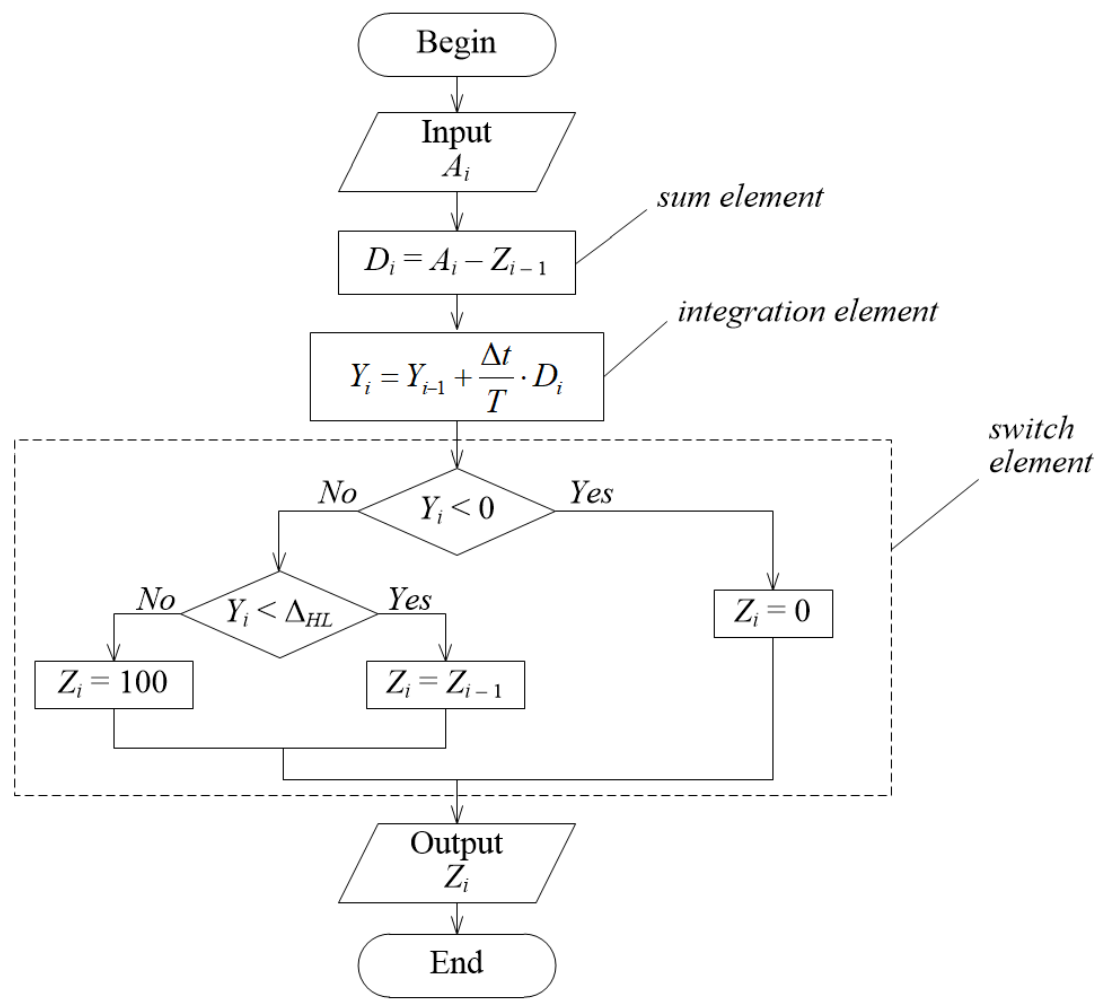

Fig.4. Simplified flowchart of PWM algorithm based on an integrator and a switch element. 
The transfer function of the diagram presented in Fig.3 can be written as

$$
W_{P W M}(s)=\frac{\frac{1}{T \cdot s} \cdot K_{s w}}{1+\frac{1}{T \cdot s} \cdot K_{s w}}=\frac{1}{\frac{T \cdot s}{K_{s w}}+1} \approx 1,
$$

where $T$ is the integrator time constant; $s$ is the Laplace transform variable; $K_{s w}$ is the switch element gain coefficient $\left(K_{s w}>>1\right)$.

We can see from (5) that PWM provides the function of proportional conversion with the coefficient of unity. It means that the duty cycle of the output pulse signal is equal to the value of the analog input signal $(\gamma=A)$. It should be mentioned that an element with the gain coefficient of unity in the control channel of an automatic control loop is called a "ballast" element.

\section{Application of PWM for controlling a thermal plant}

A thermal plant (i.e. an electric oven) is taken for investigation as a controlled plant. One of the features of such a plant is its high inertia and long duration of transient processes in it. That is why a two-point switch controller is usually applied for controlling a thermal plant. This controller is simple and it can be tuned easily. The diagram of the control channel with a two-point switch controller is presented in Fig.5.

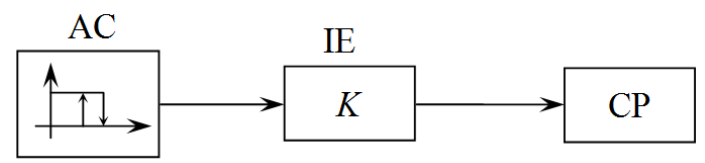

Fig.5. The diagram of the control channel with a two-point switch controller: AC is an automatic controller; IE is an intermediate element (an amplifier); CP is a controlled plant.

The example of the transient process in an automatic control loop (ACL) with a two-point switch controller is presented in Fig.6. An electric oven (SUOL-0,15.2/12M) with air flow through it was the controlled plant. Electric power at the oven input was the controlling action. And air temperature at the oven output was the process variable. The detailed description of this controlled plant is presented in [4].

The transient process presented in Fig. 6 was obtained by applying the mathematical model of the controlled plant [4] in the programmable-logic controller (PLC) MIK-51H of Microl Company [5]. PLC Jazz (JZ10-11-R16) of Unitronics company [6] was the automatic controller. MIK-registrator 1.1.14 [7] software was applied for signals logging. This software provides the possibility of logging a number of signals with the period of $1 \mathrm{~s}$. The two-point switch controller was tuned according to the following condition: it was $\mathrm{ON}$ when the temperature was below $59.5{ }^{\circ} \mathrm{C}$ and it was OFF when the temperature was higher than $60.5^{\circ} \mathrm{C}$.

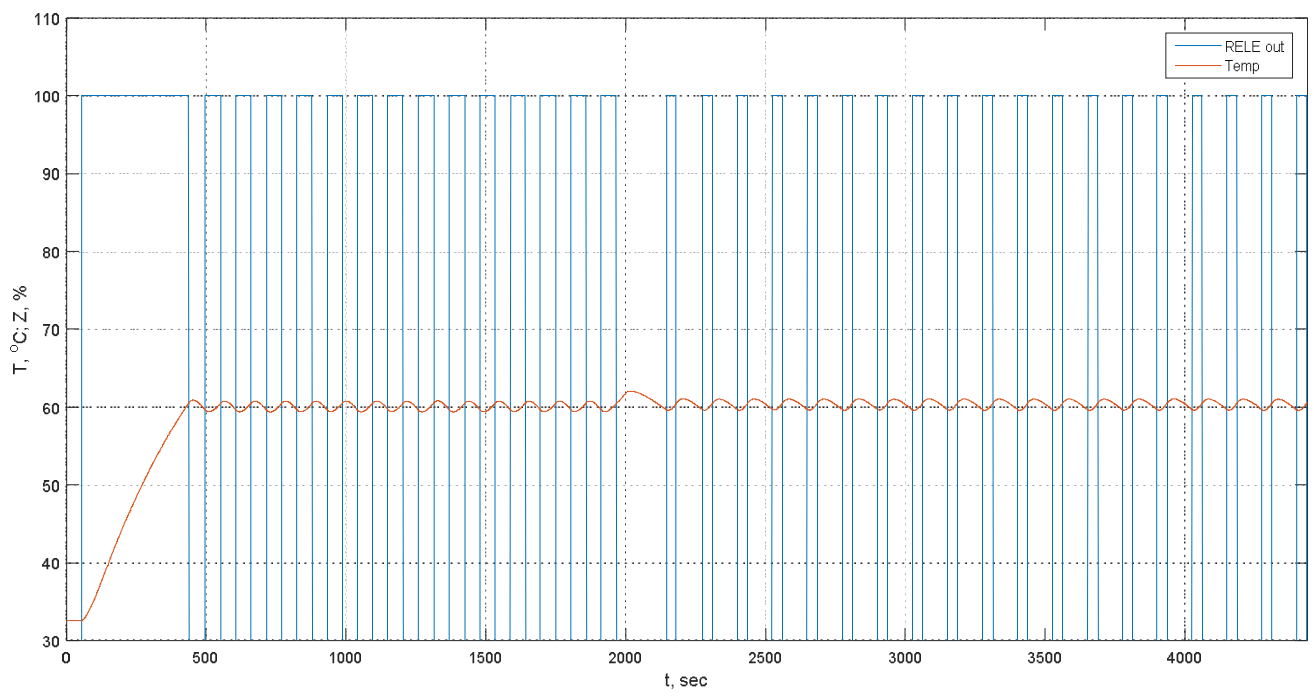

Fig.6. Transient process in ACL with a two-point switch controller. 
The transient process presented in Fig. 6 consists of two parts. The first part $(0 \ldots 1980 \mathrm{~s})$ is movement of the system to the nominal operating regime. And the second part $(1980 \mathrm{~s}$...) is processing of the disturbance introduced by reducing the air flow rate through the oven. The period of pulses at the end of the first part of the transient process is $107 \mathrm{~s}$, the duty cycle is $50 \%$ and the maximum amplitude of the process variable oscillations is $0.8{ }^{\circ} \mathrm{C}$. At the end of the second part of the transient process the period of pulses is $125 \mathrm{~s}$, the duty cycle is $30 \%$ and the maximum amplitude of the process variable oscillations is $1.0^{\circ} \mathrm{C}$.

A shortcoming of a two-point switch controller is that there is a self-oscillating transient process in the ACL. The amplitude of the process variable oscillations may be reduced by making a smaller hysteresis loop width in the two-point switch controller. However there is a minimum value below which the hysteresis loop width may not be set. And this value is defined by the measurement error of the transducer of the process variable.

In order to remove the self-oscillations in ACL a PID controller with PWM is applied [8], [9]. In this case the period of pulses at the input of the controlled plant is much smaller than that in case of a two-point switch controller application. The period of pulses is set to a specific value during adjustment of PWM algorithm. And the duty cycle is defined by the PID controller output signal. The diagram of the control channel with a PID controller and PWM is presented in Fig.7. The transient process in ACL based on the PID controller with PWM is presented in Fig.8.

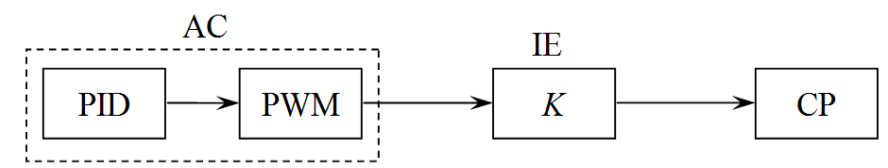

Fig.7. The diagram of the control channel with a PID controller and PWM: AC is an automatic controller; $\mathrm{IE}$ is an intermediate element (an amplifier); $\mathrm{CP}$ is a controlled plant.

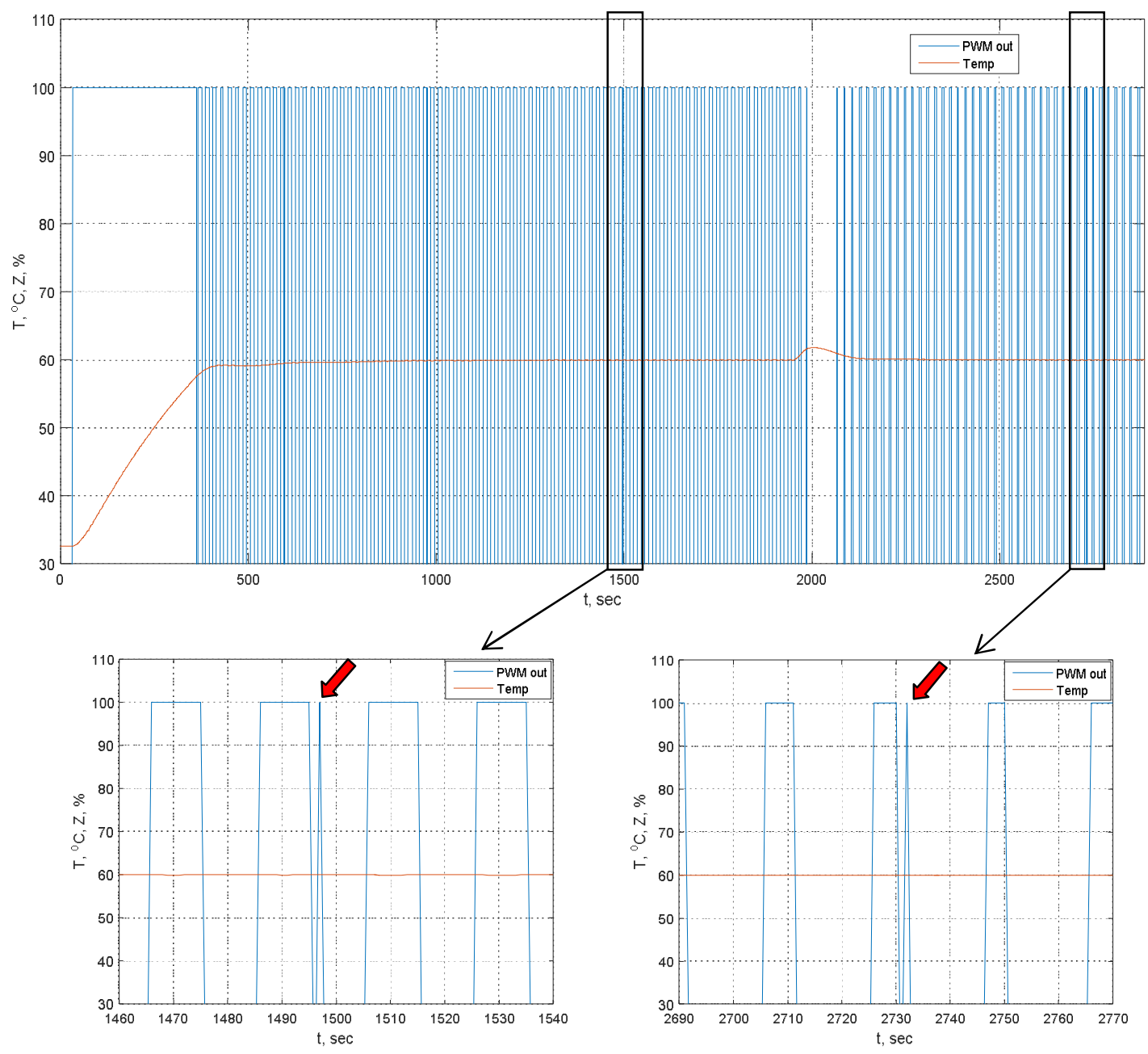

Fig.8. Transient process in ACL with a PID controller and PWM (PWM algorithm based on the sawtooth waveform generator). 
The transient process presented in Fig. 8 was obtained with application of the PWM algorithm based on the sawtooth waveform generator. The flowchart of this algorithm is presented in Fig.2. PLC Jazz (JZ10-11-R16) was applied for implementation of PID controller with PWM. The period of pulses was $20 \mathrm{~s}$. The tuning parameters of the PID controller correspond to the following values: proportional gain coefficient $K_{P}=30 \% /{ }^{\circ} \mathrm{C}$, reset time $T_{F}=200 \mathrm{~s}$, differentiation time $T_{D}=0 \mathrm{~s}$.

It can be seen from Fig. 8 that there are no self-oscillations in ACL based on PID controller with PWM. And the temperature is maintained at the set point $\left(60^{\circ} \mathrm{C}\right)$. However, frequent (redundant) operation of the controller output relay contact (contact bouncing) was observed during the transient process. It can be seen from the registered trend of the transient process (Fig.8, zoomed in figures) where there is a short pulse after a long one. It should be mentioned that the trend in Fig. 8 was registered with the step of 1 point per second. It means that there was sampling of the signal in time. That is why not all the redundant triggerings of the relay contact were registered but only those which occurred during the signal sampling and recording. All the redundant triggerings of the relay contact could be heard during the experiment. There were many more redundant triggerings of the relay contact than it was registered in the trend presented in Fig.8. In order to eliminate this undesirable phenomenon (contact bouncing) an improved algorithm of PWM is suggested.

\section{Improved PWM algorithm for thermal plant control}

Frequent (redundant) operation of the controller output relay contact (contact bouncing) which was observed during the transient process presented in Fig. 8 was caused by the high frequency oscillation of the controller digitized analog input signal. This oscillation occurred at the result of the analog-to-digital converter operation and due to existence of noise in the analog input signal. Since PLC Jazz works only with integer variables and the input signal cannot be filtered in this controller there is an oscillation of the digitized analog input signal. This oscillation is amplified by the proportional component of PID control law if $K_{P}$ is greater than unity. And it leads to a significant oscillation of the PID output analog signal. And this signal is the duty cycle set point for PWM. As a result, the PWM comparator which produces the out pulses triggers too often. This phenomenon is depicted schematically in Fig.9.

We can see from Fig.9 that contact bouncing may occur only at the end of the pulse when there is a linear change of the integrator output signal. It also can be seen from Fig. 8 where there is a short pulse only after a long one. There can be no contact bouncing at the beginning of the pulse since when the pulse appears (contact triggers from " 0 " to "1") the integrator output signal changes instantaneously from $Y_{\max }$ to zero in a step way (see Fig.9).

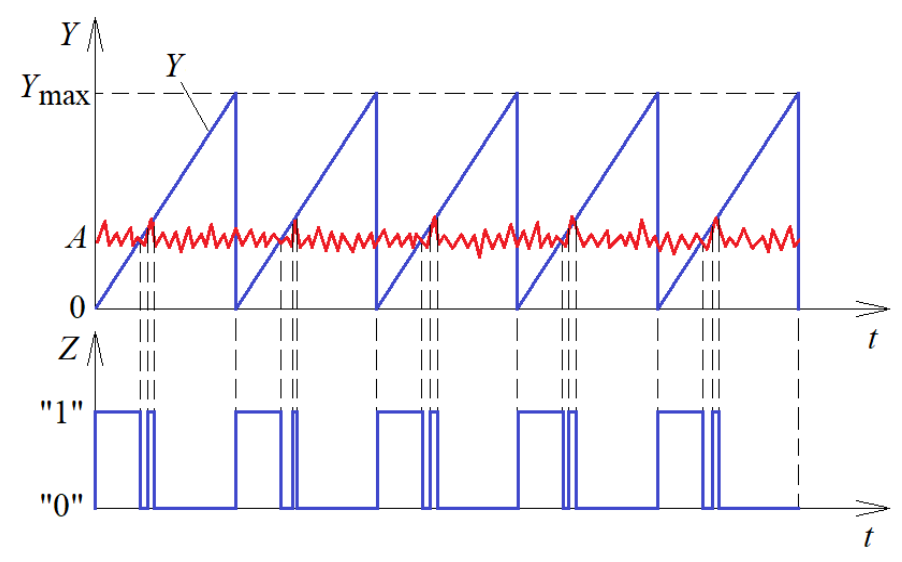

Fig.9. Dynamic characteristics of PWM operation when there is contact bouncing.

It is suggested to improve the PWM algorithm based on the sawtooth waveform generator in order to eliminate the contact bouncing. The improvement consists in introduction of one more comparator for comparing the integrator output signal $(Y)$ with the shifted signal of the duty cycle set point $\left(A-\Delta_{A}\right)$. The improved PWM algorithm is presented in Fig.10. This algorithm is accomplished within one scan cycle of the controller.

Part of the program (in U90Ladder software being applied for PLC Jazz programming) with the improved PWM algorithm and with the ordinary PWM algorithm based on the sawtooth waveform generator is presented in Fig.11. The dynamic characteristics of the improved PWM algorithm operation (without contact bouncing) is presented in Fig.12. The registered transient process in ACL based on the PID controller with the improved PWM algorithm is presented in Fig.13. 


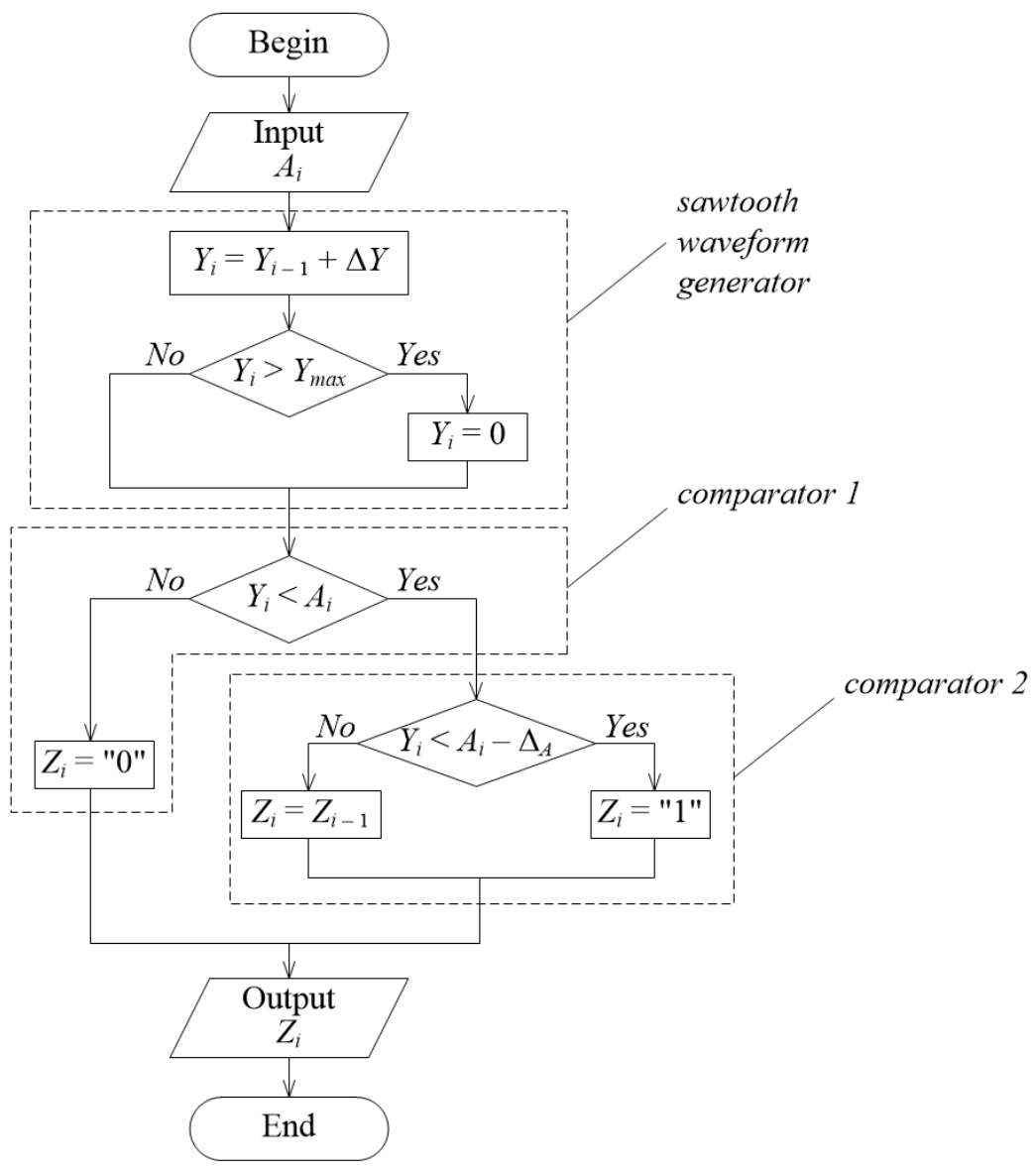

Fig.10. Simplified flowchart of the improved PWM algorithm.

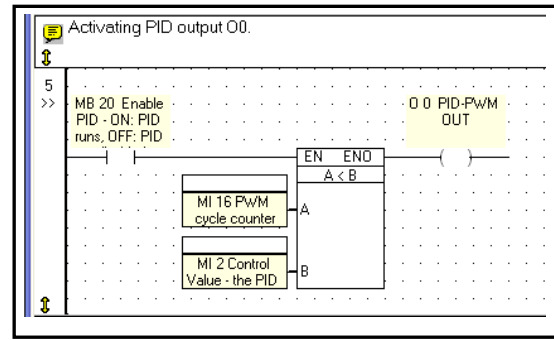

$a$

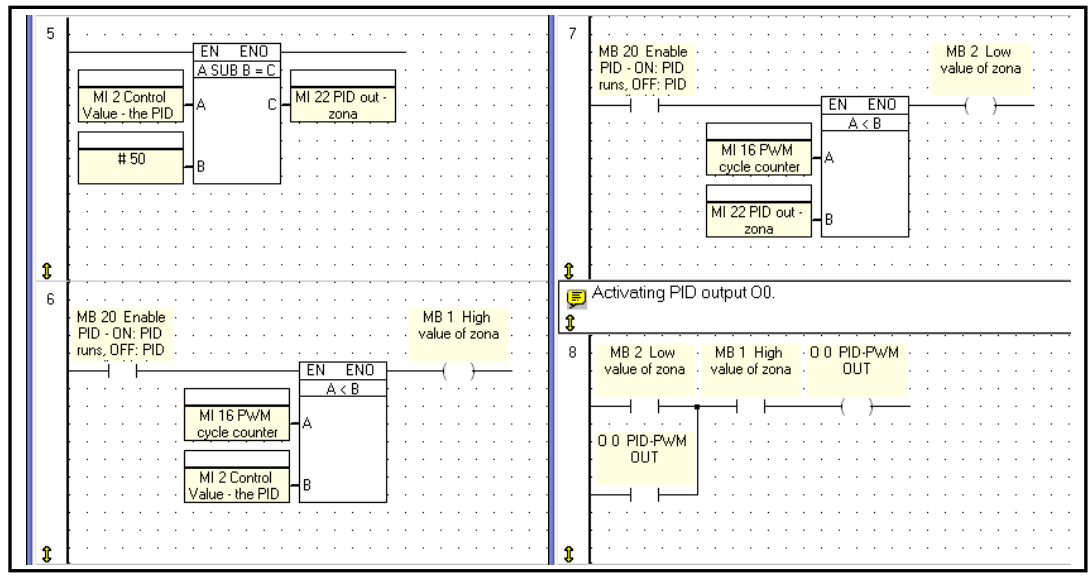

$b$

Fig.11. Part of the program in U90Ladder software: $a$ - ordinary PWM algorithm; $b$-improved PWM algorithm.

It can be seen from Fig.13 that there are no self-oscillations in ACL based on the PID controller with the improved PWM. And the temperature is maintained at the set point $\left(60^{\circ} \mathrm{C}\right)$. There was no contact bouncing during the transient process in ACL based on the PID controller with the improved PWM algorithm. It can be seen from Fig.13 (zoomed in figures) where there are only long pulses and no short pulses. 


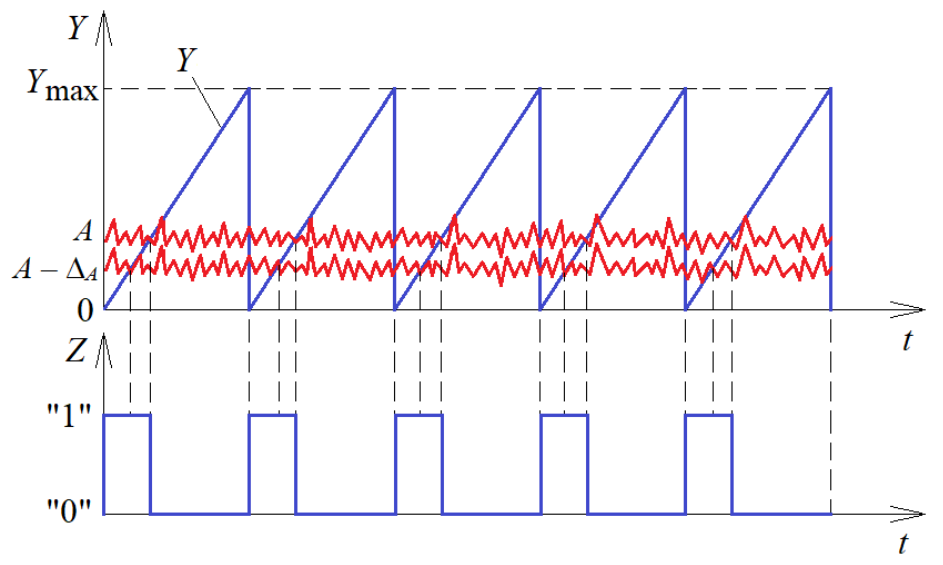

Fig.12. Dynamic characteristics of the improved PWM algorithm operation.

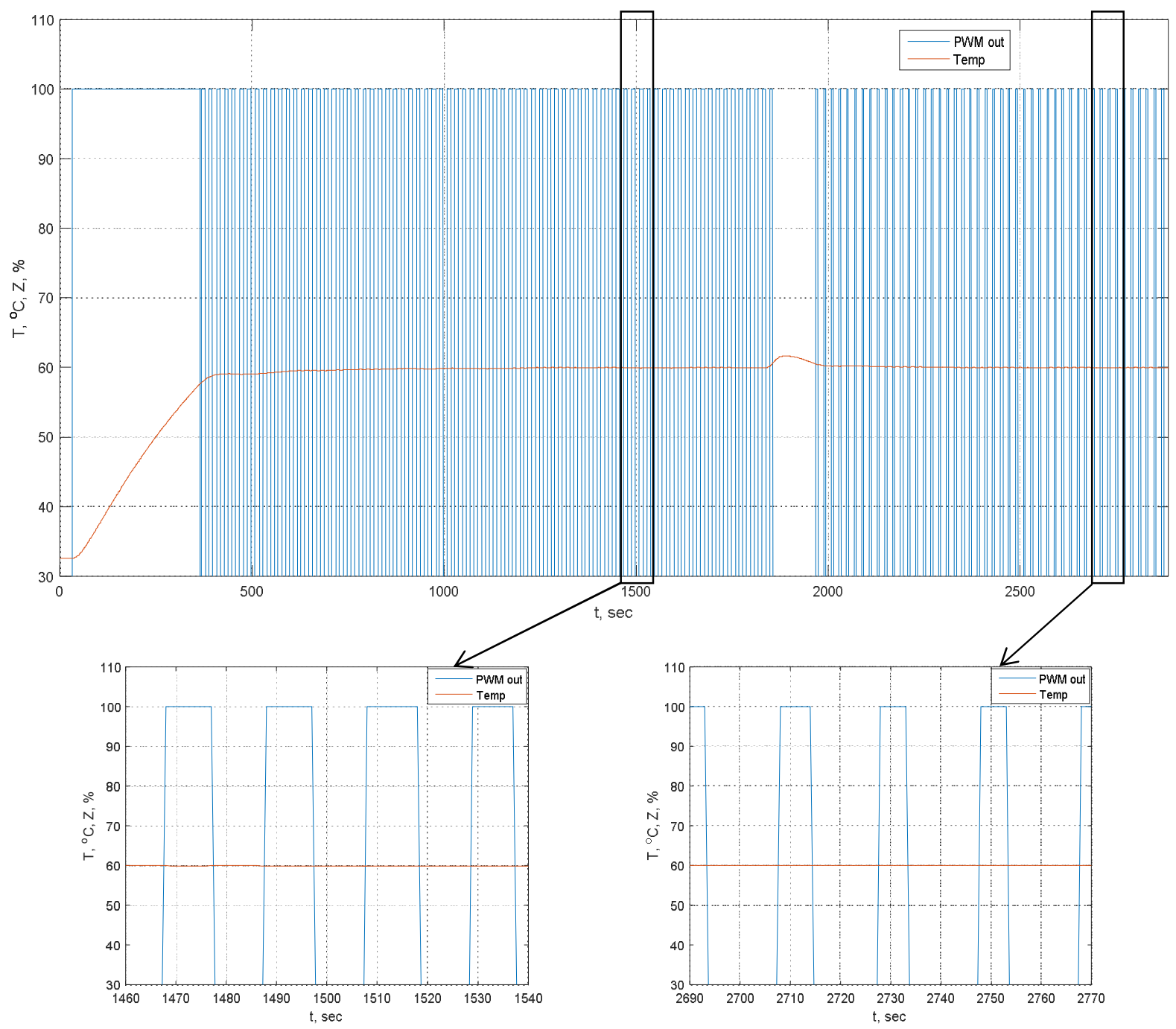

Fig.13. Transient process in ACL based on the PID controller with the improved PWM algorithm.

The transient process presented in Fig. 13 consists of two parts. The first part $(0 \ldots 1860 \mathrm{~s})$ is movement of the system to the nominal operating regime. And the second part $(1860 \mathrm{~s} \ldots)$ is processing of the disturbance introduced by reducing the air flow rate through the oven. The period of pulses at the end of the first part of the transient process is $20 \mathrm{~s}$ and the duty cycle is $50 \%$. At the end of the second part of the transient process the period of pulses is $20 \mathrm{~s}$ and the duty cycle is $30 \%$. 
Thus, by applying the improved PWM algorithm in the controller the influence of oscillations of the digitized analog input signal on the output pulse signal is eliminated. Frequent (redundant) operation of the controller output relay contact (contact bouncing) is avoided. And it is the main advantage of the improved algorithm. The suggested algorithm provides improvement of PLC reliability and a longer operation time of PLC output relay contact.

\section{Definition of PWM pulse period for controlling a thermal plant}

There is often the problem of defining the PWM pulse period for controlling a thermal plant. This problem can be solved with taking into account the dynamical properties of the controlled plant (CP). In general case the bigger the inertia of $\mathrm{CP}$ the longer period of pulses at PWM output can be and vice versa.

Since the main principle of PWM application for controlling a thermal plant is that CP behaves like a filter, the period of pulses (and their frequency) at $\mathrm{CP}$ input must be of such a value that $\mathrm{CP}$ output variable in the equilibrium state is uniform without any oscillations. And this can be reached only when the frequency of the input pulses is sufficiently high for the pulses to be filtered by CP. The numerical value of the pulses frequency (and period) for a specific $\mathrm{CP}$ can be defined on the basis of $\mathrm{CP}$ frequency response characteristics.

Let us consider PWM application for controlling the plant under investigation in this work (electric oven). The dynamical model of this plant for the control action channel can be presented by means of the following transfer function [4]

$$
W_{C P}^{x}(s)=\frac{k_{x}}{\left(a_{x} s+1\right)} \cdot \frac{1}{\left(b_{x} s+1\right)},
$$

where $k_{x}$ is the $\mathrm{CP}$ gain coefficient $\left(k_{x}=0.5446{ }^{\circ} \mathrm{C} / \%\right) ; a_{x}, b_{x}$ are the $\mathrm{CP}$ time constants $\left(a_{x}=499.55 \mathrm{~s}, b_{x}=25.22 \mathrm{~s}\right)$.

The normalized frequency response curve of $\mathrm{CP}$ was built on the basis of the transfer function (6). This curve is presented in Fig.14.
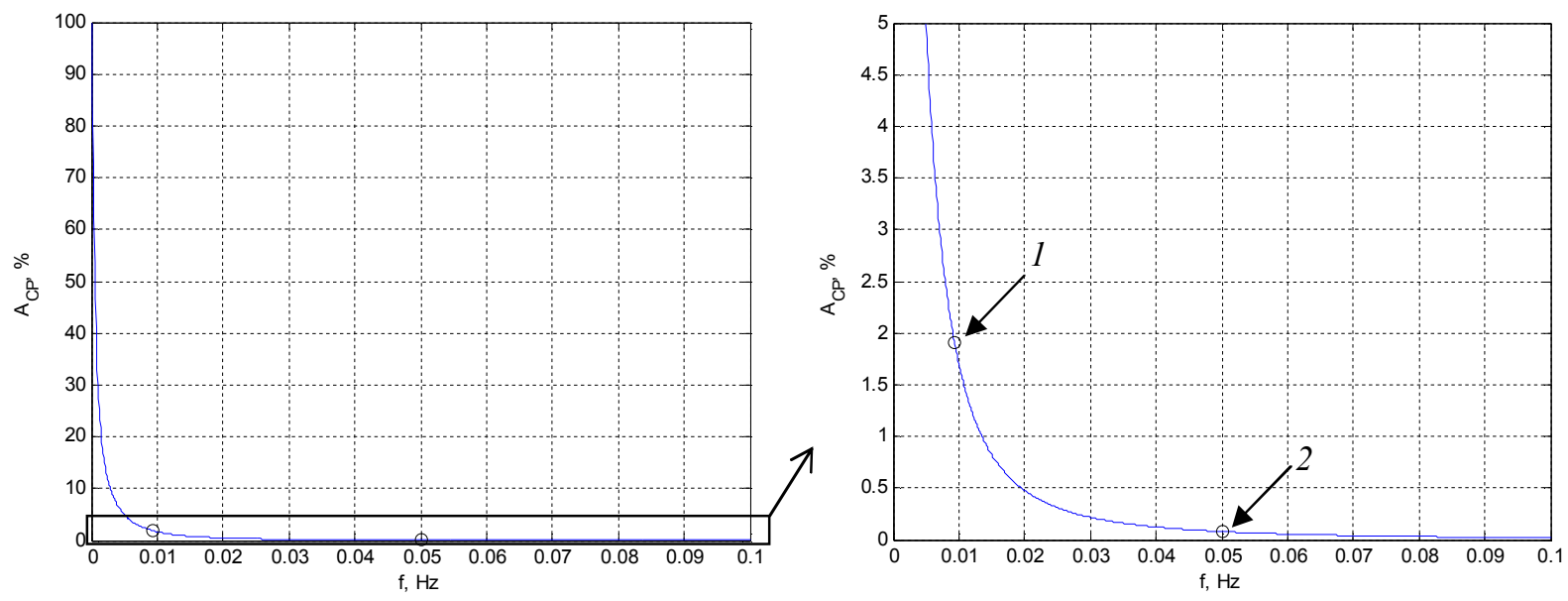

Fig.14. Normalized frequency response curve of CP: 1 - two-point switch controller; 2 - PID controller with PWM.

There are two points marked on the curve in Fig.14. The first point corresponds to the frequency of CP input pulses at the equilibrium state when the two-point switch controller was applied. And the second point corresponds to the frequency of CP input pulses at the equilibrium state when the PID controller with PWM was applied.

The frequency in point 1 in Fig. 14 is $0.0093 \mathrm{~Hz}$ and it corresponds to the period of pulses $107 \mathrm{~s}$. The normalized amplitude in point 1 is $1.91 \%$. The oscillations at CP output are significant at such a value of amplitude (1.91\%). And it can be seen from the transient process in Fig.6.

The frequency in point 2 in Fig. 14 is $0.05 \mathrm{~Hz}$ and it corresponds to the period of pulses $20 \mathrm{~s}$. The normalized amplitude in point 2 is $0.08 \%$. There are no oscillations at $\mathrm{CP}$ output in the equilibrium state at such a value of amplitude $(0.08 \%)$. And it can be seen from the transient process in Fig. 13.

Thus, the criterion for defining the frequency of PWM output pulses might be such a value of frequency at which the normalized frequency response characteristics of $\mathrm{CP}$ does not exceed $0.1 \%$. It should be mentioned here that the pulses frequency should not be too high in order to avoid fast wearing-out of the relay contact. 


\title{
7. Conclusion
}

The algorithms of pulse-width modulation were analyzed. PWM based on the sawtooth waveform generator and PWM based on an integrator and a switch element was analyzed. Mathematical formulae were defined for designing the tuning parameters of these algorithms. The example of PWM application in an automatic controller for controlling a thermal plant was presented. The comparison of the transient processes quality in ACL based on a two-point switch controller and based on the PID controller with PWM was made. Since the contact bouncing may occur in ACL based on the PID controller with PWM an improved PWM algorithm was suggested for eliminating this undesirable phenomenon. PWM algorithm based on the sawtooth waveform generator was improved. The improvement consists in introduction of one more comparator for comparing the integrator output signal $(Y)$ with the shifted signal of the duty cycle set point $\left(A-\Delta_{A}\right)$.

The technique for defining the PWM output pulses period is suggested with taking into account the dynamical properties of the controlled plant. This technique provides the possibility to define such a value of the pulses period at which there are no oscillations of the controlled plant output variable in the equilibrium state. Application of the improved PWM algorithm and the technique for defining the period of PWM output pulses provides longer service time of the controller output relay contact. It also provides improvement of the reliability of the controller operation.

\section{References}

[1] S. Kril, R. Fedoryshyn, O. Kril, Y. Pistun. Investigation of Functional Diagrams of Step PID Controllers for Electric Actuators // Procedia Engineering, Volume 100, 2015, Pages 1338-1347. doi: 10.1016/j.proeng.2015.01.549

[2] Y. I. Topcheev. Atlas for designing the automatic control systems. Moscow, "Mashinostroenie". 1989. - 752 p. (in Russian)

[3] Microprocessor programmable control devices PROTAR. Information materials (gEZ. 222.030 D20) Moscow Thermal Automation Works. 1987. (in Russian)

[4] R. Fedoryshyn, S. Klos, V. Savytskyi, O. Masniak. Identification of Controlled Plant and Development of Its Model by Means of PLC. Energy Eng. Control Syst., 2016, Vol. 2, No. 2, pp. 69 - 78. https://doi.org/10.23939/jeecs2016.02.069

[5] MIK-51H Microprocessor Controller. Operations Manual. PRMK.421457.006RE1. Microl Enterprise. Ivano-Frankivsk, 2015. - 82 p (in Russian)

[6] Jazz Micro-OPLC. Operating Panel and Programmable Logic Controller. Operations Manual. Unitronics. $2006 .-34$ p. (in Russian)

[7] “MIK-registrator” Software. Version 1.1.14. Operations Manual PRMK.426000.002RE. Microl Enterprise. Ivano-Frankivsk, 2010 - 19 p. (in Russian)

[8] S. Klos, R. Fedoryshyn, V. Savytskyi, Y. Pistun, F. Matiko (2017). Classification of Automatic Controllers Diagrams. Proceedings of the 28th DAAAM International Symposium, Pages 0967-0973. DOI: 10.2507/28th.daaam.proceedings.134

[9] J.-K. Woo, D. Yang, K. Najafi, S. Lee, J. Mitchell. (2016). Miniaturized digital oven-control microsystem with high power efficiency and \pm 1.8 ppm frequency drift. Frequency Control Symposium, 2016 IEEE International, pp. 1 - 4. DOI: 10.1109/FCS.2016.7563578.

\section{Удосконалення алгоритму широтно-імпульсної модуляції для керування тепловим об'єктом}

\author{
Роман Федоришин, Святослав Кльось, Володимир Савицький, Сергій Кріль \\ Національний університет «Львівська політехніка», вул. Степана Бандери, 12, Львів, 79013, Україна
}

\section{Анотація}

Представлено результати аналізу алгоритмів широтно-імпульсної модуляції (ШІМ), а саме ШІМ на базі генератора пилкоподібних коливань та ШІМ на базі інтегруючої ланки та релейного елемента. Наведено математичні залежності для визначення параметрів налаштувань цих алгоритмів. Запропоновано удосконалений алгоритм ШІМ для умов роботи контролера 3 цілочисельними змінними без фільтра вхідного сигналу. Удосконалений алгоритм забезпечує усунення впливу шумів вхідного аналогового сигналу регулятора на його імпульсний вихідний сигнал, а також дає можливість уникнути таке небажане явище як брязкіт вихідного релейного контакту контролера. Завдяки цьому досягається підвищення надійності функціонування контролера та збільшення часового ресурсу роботи його вихідних релейних контактів. Наведено приклад застосування ШІМ у складі автоматичного регулятора для керування тепловим об’єктом. Продемонстровано переваги удосконаленого алгоритму ШІМ та обгрунтовано доцільність його застосування. Представлено спосіб вибору періоду імпульсів для ШІМ з врахуванням динамічних властивостей об’єкта регулювання.

Ключові слова: широтно-імпульсний модулятор; алгоритм; шпаруватість; інтегратор; компаратор; реле. 